\title{
REGULATORY APPROACHES TO SOCIAL MEDIA
}

\author{
Balázs Bartóki-Gönczy ${ }^{1}$
}

DOI: 10.24989/ocg.338.27

\begin{abstract}
Social media platforms are mainly characterised by private regulation. ${ }^{2}$ However, their direct and indirect impact on society has become such (fake news, hate speech, incitement to terrorism, data protection breaches, impact on the viability of professional journalism) that private regulatory mechanisms in place (often opaque and not transparent) seem to be inadequate. In my presentation, I would first address the problem of legal classification of these services (media service provider vs. intermediary service provider), since the answer to this question is a prerequisite for any state intervention. I would then present the regulatory initiatives (with a critical approach) at EU and national level which might shape the future of 'social media platform' regulation.
\end{abstract}

\section{Introduction}

Social networks allow any citizen to publish the content of their choice and share it with other network users. They have revolutionized the media industry and the ways of communication by offering citizens and civil society a medium for direct expression. The appeal to mainstream media is no longer required to communicate publicly. The possibility for citizens to exercise their freedoms of expression, communication, and information are therefore considerably increased by these services. However, the capabilities offered by social networks give rise to unacceptable abuses of these freedoms. These abuses are committed by isolated individuals or organized groups to which large social networks, Facebook, YouTube, Twitter or Snap, to name a few, do not fully answer satisfactory to date. However, by the scheduling that they produce published content and by their policy of moderation, social networks are able to act directly on these most obvious abuses for prevent or respond to them and thus limit damage in terms of social cohesion. ${ }^{3}$

Even Mark Zuckerberg (CEO of Facebook) has recognized that "we need active role for governments and regulators. By updating the rules for Internet, we can reserve what's best about it - the freedom for people to express themselves and for entrepreneurs to build new things - while also protecting society from broader harm."

\footnotetext{
${ }^{1}$ National University of Public Service, Hungary, Assistant Professor, bartoki-gonczy.balazs@uni-nke.hu

${ }^{2}$ In the context of the present study, we mean private regulation as a set of rules applied by platforms to their own activities. By contrast, self-regulation is defined as the rules for private market participants being laid down by an independent body separate from them but composed of their members. Co-regulation is understood as a system where the State cooprate with representative bodys of private entities. We mean co-regulation where the state defines the frame of the rules defined by private operators and controls their execution.

${ }^{3}$ Créer un cadre français de responsabilisation des réseaux sociaux: agir en France avec ambition européenne, Rapport de de la mission 'Régulation des réseaux sociaux - Expérimentation Facebook', Secrétaire d'État chargé du numérique, 2019., https://www.vie-publique.fr/sites/default/files/rapport/pdf/194000427.pdf, (21-01-2020).

${ }^{4}$ The Internet needs new rules. Let's start in these four areas, The Washington Post, https://www.washingtonpost.com/ gdpr-consent $/$ destination $=\% 2$ fopinions $\% 2$ fmark-zuckerberg-the-internet-needs-new-rules-lets-start-in-these-fourareas\%2f2019\%2f03\%2f29\%2f9e6f0504-521a-11e9-a3f7-78b7525a8d5f_story.html\%3f (24-01-2020)
} 
The challenge is how can we ensure the right to access to information and protect the users from online abuses. From a legal point of view, how should we definy and regulate the social media platforms? In this paper I aim to highlight some of these legal challenges and to show the most likely way the EU will go on with the revision of the Electronic Commerce Directive (hereinafter: ECommerce Directive).

\section{Legal classification of the social media service}

\subsection{The evolution of the audiovisual media service' notion}

Large Internet gatekeepers consider themselves tech companies. As Koltay mentions, it is their best interest to do so, for two reasons. First, the regulations applicable to technology companies are far narrower and less stringent than those applicable to media companies (which are also subject to content regulation, special restriction on competition, the prohibition of concentration, and the obligation to perform public, interest tasks). Second, the moral requirement of social responsibility is far less frequently mentioned concerning the activities of tech companies.[5]

The E-Commerce Directive ${ }^{5}$ and the Audiovisual Media Services Directive ( hereinafter "the AMS Directive" $)^{6}$ seek to separate information society services from media services. According to the ECommerce Directive, a service whereby the service provider selects or modifies the information transmitted is not an information society service within the scope of Directive. On the other hand, the AMS Directive excludes from its scope services that do not have "effective control" over the content in question.

However, as a result of convergence, it is becoming increasingly difficult to determine clearly whether an online intermediary activity involves "selection" of content or exercising "effective control" over it.[4] It is enough to think only about content selection by algorithms. The EU legislator also seeks to adapt flexibly to the challenges of the age and to dynamically shape the concept of media service. Therefore, where the concept of media service is constantly expanding, the most delicate question is where to draw the line. Whether Facebook and other social media are still "technical" mediators or they behave more like "media" service. To determine this, we will analyze below the concept of dynamically changing media services, with particular reference to the future classification of social media services and video sharing platforms.

The scope of media services has been expanding over the last 30 years, albeit with cautious steps, but also in order to keep pace with the changing market environment, consumer habits and technological developments. The concept, codified in the AMS Directive adopted in 2010, makes the editorial responsibility the heart of the definition. According to the Directive, audiovisual media service is:

"a service as defined by Articles 56 and 57 of the Treaty on the Functioning of the European Union which is under the editorial responsibility of a media service provider and the principal purpose of which is the provision of programs, in order to inform,

\footnotetext{
${ }^{5}$ Directive 2000/31/EC of the European Parliament and of the Council of 8 June 2000 on certain legal aspects of information society services, in particular electronic commerce, in the Internal Market ('Directive on electronic commerce'), OJ L 178

${ }^{6}$ Directive 2010/13/EU of the European Parliament and of the Council of 10 March 2010 on the coordination of certain provisions laid down by law, regulation or administrative action in Member States concerning the provision of audiovisual media services (Audiovisual Media Services Directive), OJ L 95,
} 
entertain or educate, to the general public by electronic communications networks within the meaning of point (a) of Article 2 of Directive 2002/21/EC. Such an audiovisual media service is either a television broadcast as defined in point (e) of this paragraph or an ondemand audiovisual media service as defined in point (g) of this paragraph." (...)."7

The 'editorial responsibility' means the exercise of effective control both over the selection of the programmes and over their organization either in a chronological schedule, in the case of television broadcasts, or in a catalogue, in the case of on-demand audiovisual media services. Editorial responsibility does not necessarily imply any legal liability under national law for the content or the services provided. ${ }^{8}$ The Directive of 2010 does not further clarify what is meant by 'selection', but in practice there may be several cases where the answer to the question is unclear.

Therefore, the Directive of 2010 excluded many services from its scope. According to its audiovisual media service definition, it covered only audiovisual media services intended for the general public and having a clear influence on it, excluding, inter alia, private websites and services in which individuals make their own audiovisual content (e.g. social media service providers).

In recent years, the EU legislator itself has recognized the need to adapt the material scope of media regulation to a rapidly changing reality. According to the European Digital Single Market Strategy adopted in $2015,{ }^{9}$ the AMS Directive needs to be updated to reflect these changes in the market, consumption and technology. On 25 May 2016, the Commission published its Amending Proposal ("the Proposal") ${ }^{10}$ explaining that the reason for the change was the emergence of new business models, which allowed new, growing and competing players on the Internet to compete for the same audience. (such as video-on-demand service providers and video sharing platforms) offering audiovisual content. However, the Commission notes that television broadcasting, on-demand video and user-generated content are subject to different rules and that there are different levels of consumer protection.

The modification of the AMS Directive has been adopted in Fall 2018. ${ }^{11}$ In terms of its scope, it represents two important changes to the Directive of 2010. The first, that the criterion of 'editorial responsibility' loses its significance in the concept of media service, focuses on the 'primary purpose' of the service:

"audiovisual media service" means: a service (...) where the principal purpose of the service or a dissociable section thereof is devoted to providing programs, under the editorial responsibility of a media service provider, to the general public, in order to inform, entertain or educate, by means of electronic communications networks (...)."12

The biggest change, however, is the point in the amendment extends the scope of media regulation to online "video sharing platforms" (with less burden compared to audiovisual media services):

\footnotetext{
${ }^{7}$ Directive 2010/13/EU, Art. 1., point 1.a)

${ }^{8}$ Directive 2010/13/EU, Art. 1., point 1.c)

${ }^{9}$ Digital Single Market Strategy for Europe, SWD(2015) 100 final

${ }^{10} \mathrm{COM}(2016) 287$ final, 2.

${ }^{11}$ Directive (EU) 2018/1808 of the European Parliament and of the Council of 14 November 2018 amending Directive 2010/13/EU on the coordination of certain provisions laid down by law, regulation or administrative action in Member States concerning the provision of audiovisual media services (Audiovisual Media Services Directive) in view of changing market realities, OJ L 303

${ }^{12}$ Directive 2018/1808, Art.1.
} 
"video-sharing platform service" means a service as defined by Articles 56 and 57 of the Treaty on the Functioning of the European Union, where the principal purpose of the service or of a dissociable section thereof or an essential functionality of the service is devoted to providing programs, user-generated videos, or both, to the general public, for which the video-sharing platform provider does not have editorial responsibility, in order to inform, entertain or educate, by means of electronic communications networks within the meaning of point (a) of Article 2 of Directive 2002/21/EC and the organization of which is determined by the video-sharing platform provider, including by automatic means or algorithms in particular by displaying, tagging and sequencing." 13

\subsection{What about social media services?}

According to the original Commission proposal, ${ }^{14}$ social media services fall within the scope of the AMS Directive only if they provide a service that meets the definition of a video-sharing platform. According to the Council's amendment proposals adopted in March 2017, social media has become an important tool for information sharing, entertainment and education. Therefore, the Council argues, social media platforms should be subject to media regulation where audiovisual content represents a significant proportion of the social media interface.

To determine what constitutes 'a significant part', it is necessary to consider (i) whether the service provider has developed a separate business model for contents shared by third parties or by itself and (ii) it is important to consider how the audiovisual content is displayed.

I agree with this position since the come social media service providers, such as Facebook, are increasingly taking on the role of "editor", having a significant and direct discretion in deciding what content may appear in users' "daily news".[1] It is a well-known fact that Facebook, Twitter, Snapchat and Instagram employ a dedicated editorial team to select the content available on their site. Twitter CEO Jack Dorsey himself stated in 2016 that "we recruited people to help us select the best tweets for Moments (...)". ${ }^{15}$

This is linked to the controversy surrounding Facebook's "Trending Stories" service launched in 2014. This "box" at the top of the sidebar of the feed was intended to display the most current and recent news and highlighted in this section the news that was read and shared by many. What was important and what was interesting was not determined by algorithms, but by an editorial team. In addition, gradually leaked documents, ${ }^{16}$ statements by insiders and former editors revealed that the selection of news had overtaken conservative sources and the Liberals were clearly favored by an editorial team whose subjective decisions were based on a written instruction. So the problem was not only that, despite Facebook's assertions, it was edited selectively, but that it was done biased. Facebook first denied the allegations, but later admitted that the personal bias of the editors could indeed have distorted the selection of news.[1]

\footnotetext{
${ }^{13}$ Directive 2018/1808, Art. 1.

${ }^{14} \mathrm{COM}(2016) 287$ final, recital 3.

15 http://www.lefigaro.fr/secteur/high-tech/2016/05/12/32001-20160512ARTFIG00332-jack-dorsey-twitter-les-annonce urs-attendent-beaucoup-de-la-video.php, (23-01-2020)

16 The Guardian: Facebook news selection is in hands of editors not algorithms, documents show, https://www.theguardian.com/technology/2016/may/12/facebook-trending-news-leaked-documents-editor-guidelines, (23-01-2020)
} 
In addition to his assumed editorial role, the so-called fake news phenomenon may also force social media service providers to take on new roles beyond the technical mediation provider. It is suspected that the Russian Federation has used the most popular social media providers as a tool to influence the US presidential election in 2016. The case may have shocked Facebook itself, which first denied that its platform was appropriate for engaging in social debate at this level, but was forced to admit, after an internal investigation, that Russian propaganda reached about 126 million (!) US citizens through the social media site ${ }^{17}$ Social media (or Facebook in particular) has a disillusioning power, and the influence and exposure of the public to fake news in the feed is a cause for concern. It has become clear that the vast majority of the population will indulge in everything they read through Facebook indiscriminately. In response, Mark Zuckerberg announced in October 2017 that they would tighten their rules on sponsored content. First, they increase transparency by displaying the advertiser alongside supported content and what other advertisers are paying for on Facebook. ${ }^{18}$

In my view, these steps point to the fact that social media service providers, due to their indisputably important role and responsibility in social debate, are taking on a number of editorial tasks, simply being no more than technical service providers. This approach is shared by Potier and Abiteboul, who consider that all content published on a social network cannot be presented to the user without scheduling. The volume of content published necessarily implies that the platform defines an order of appearance, makes a selection, while leaving the user the possibility of searching, at his initiative, specific content. The content that he will actually consult will primarily depend on the layout of its interface and the use of algorithmic rules to prioritize and individualize the presentation of the different contents. The existence of this information structuring function plays an essential role in the dissemination of content and in the capacity of social networks to prevent or accentuate damage to social cohesion. The observation of the existence of this content scheduling function, which constitutes a form editorial de facto cannot call into question the legal status of these actors, nor lead to them requalify as publishers when the majority of social network services do not select prior to the publication of content. ${ }^{19}$

\section{Fight against illegal content on social media networks}

\subsection{Responsibility in general of social media service providers for illegal content}

Depsite the tendencies described above, Under EU law, social media platforms are still considered to be 'hosting service providers', as the users of such services store, sort and make available their own content in and through the systems. This means that, pursuant to the E-Commerce Directive, the platforms are required to remove any violating content after they become aware of tis infringing nature, but they may not be subject to any general monitoring and control obligation.[3]

Nevertheless, a tendency to challenge this principle could be observed recently. The Court of Justice of the European Union (hereinafter: CJEU), in its judgment C-18/18 of 3 October 2019, ruled that the Directive does not preclude a national court to order a host provider to remove content identical or

17 The Guardian: Tech giants face Congress as showdown over Russia election meddling looms, https://www.theguardian.com/technology/2017/oct/22/facebook-google-twitter-congress-hearing-trump-russia-election, (23-01-2020)

18 Guiding Techs: 5 Ways Facebook Will Improve Transparency in Ads and Avoid Fake News, https://www.guidingtech.com/73648/facebook-ads-transparency-enforcement/, (23-01-2020)

${ }^{19}$ Créer un cadre français de responsabilisation des réseaux sociaux: agir en France avec ambition européenne (2019), p. 9. 
equivalent to a message previously declared unlawful, provided that the message (i) remains essentially unchanged and (ii) does not require an independent assessment from the host provider. ${ }^{20}$ As the CJEU notes, "although Article 15(1) [of the E-Commerce Directive]prohibits Member States from imposing on host providers a general obligation to monitor information which they transmit or store, or a general obligation actively to seek facts or circumstances indicating illegal activity, (...), such a prohibition does not concern the monitoring obligations 'in a specific case.,"21

Such a specific case may, in particular, be found, in a particular piece of information stored by the host provider concerned at the request of a certain user of its social network, the content of which was examined and assessed by a court having jurisdiction in the Member State, which, following its assessment, declared it to be illegal. According to the CJEU, in order to ensure that the host provider at issue prevents any further impairment of the interests involved, it is legitimate for the court having jurisdiction to be able to require that host provider to block access to the information stored, the content of which is identical to the content previously declared to be illegal. In particular, in view of the identical content of the information concerned, the injunction granted for that purpose cannot be regarded as imposing on the host provider an obligation to monitor generally the information which it stores, or a general obligation actively to seek facts or circumstances indicating illegal activity. ${ }^{22}$

In the same vein, the draft French Bill on Countering Online Hatred ("loi Avia"), as amended in first reading by the National Assembly, ${ }^{23}$ intended to impose a "notice and stay down" obligation on online platforms stating that appropriate means have to be implemented to prevent any re-publication of online content that has already been removed. However, strong objections to an erosion of the host provider's liability principle have been raised.

The European Commission argued that the article of the French Bill was a potential breach of the article 15 of the E-commerce Directive as it creates a general obligation of monitoring, and underlined the limited impact of the CJUE Judgement (C-18/18). The Commission pointed out that, in the CJEU case law, the obligation came from a court injunction and only concerned specific content. These conditions, according to the Court, provide to the injunction the appropriate guarantees and the required proportionality to be compatible with the Directive. Unlike the provision in the French Bill, it does not create a general monitoring obligation. The European Commission also underlines that this provision is likely to interfere with the future Digital Service Act. ${ }^{24}$

\subsection{Towards a co-regulatory model?}

Although the French law amendment is far from certain to be approved by the Senate, initiatives by the CJEU and the French government show that reform of the liability system will be a central issue in the 2020 revision of the E-Commerce Directive. Perhaps one of the most important issues is that, in the future, rules on the removal of infringing content will continue to be set entirely by the service providers themselves or State oblige service providers to comply with certain procedural rules in order to enhance transparency.

\footnotetext{
${ }^{20} \mathrm{https}$ //www.epra.org/news_items/blocking-access-to-content-previously-declared-unlawful-a-new-obligation-on-theplatform, (01-24-2020)

${ }^{21}$ Judgment of the Court In Case C-18/18,point 34.

22 Judgment of the Court In Case C-18/18,points 35-37.

${ }^{23} \mathrm{http} / /$ www.assemblee-nationale.fr/15/ta/ta0310.asp, (24-01-2020)

${ }^{24} \mathrm{https}$ //www.epra.org/news_items/blocking-access-to-content-previously-declared-unlawful-a-new-obligation-on-theplatform, (01-24-2020)
} 
Social networking sites in many ways go beyond a classical state law jurisdiction. The frontier of services only contributes to the fact that community platforms are a teacher of nation-state sovereignty in some cases remain resistant. At the same time, social networking service providers usually make their own rules that essentially define the framework for the expression, limits and procedures that can be applied in the event of a breach of these mechanisms also introduced. Rules created by service providers essentially create a specific "content control", and these rules, say, on the state media control platform mappings.[5]

As a French report mentions. neither the public authorities nor civil society know what value to place on social media statements. They share, with a few exceptions, the same level of information as a user. All the information made public by the platform concerning its private regulatory action cannot be corroborated by any observable fact. This limit is consubstantial with the operation of the main social network services due to the individualization of the content offered. Creating an account on the platform allows you to observe only a tiny fraction. Only the platform can measure the effects on a global scale. This lack of credibility is increased by the huge volume of content and users of social networks, which necessarily involve algorithmic processing in a statistical approach. Without being able to characterize the existence of a systemic failure of the social network, public authorities as well as representatives of civil society can only point to individual cases of unmodified or poorly moderated content. These isolated failures are however not sufficient to characterize a potential systemic failure. $^{25}$

\subsubsection{Germany: a national approach}

In response to this problem, the German legislator has adopted in 2017 an Act aiming to "improve enforcement of the law in social media networks (hereinafter: NetzDG). ${ }^{26}$ The Act applies to "telemedia service providers" which, for profitmaking purposes, operate internet platforms which are designed to enable users to share any content with other users or to make such content available to the public (social networks). Platforms offering journalistic or editorial content, the responsibility for which lies with the service provider itself, shall not constitute social networks within the meaning of this Act. The same shall apply to platforms which are designed to enable individual communication or the dissemination of specific content. The Act applies only to social media network providers having more than two million registered users in Federal Republic of Germany. ${ }^{27}$ The NetzDG imposes obligations in two important areas: (i) reporting and (ii) handling of complaints about unlawful content.

As far as the reporting obligation is concerned, it applies to providers of social networks which receive more than 100 complaints per calendar year about unlawful content. The service providers concerned are obliged to produce half-yearly German-language reports on the handling of complaints about unlawful content on their platforms and shall be obliged to publish these reports in the Federal Gazette and on their own website no later than one month after the half-year concerned has ended. The reports published on their own website shall be easily recognizable, directly accessible and permanently available. The reports shall cover:

\footnotetext{
${ }^{25}$ Créer un cadre français de responsabilisation des réseaux sociaux (2019), p. 12.

${ }^{26}$ https://www.bmjv.de/SharedDocs/Gesetzgebungsverfahren/Dokumente/NetzDG_engl.pdf?_blob=publicationFile\&v $=2,(24-01-2020)$

${ }^{27}$ NetzDG, Art. 1.
} 
- $\quad$ general observations outlining the efforts undertaken by the provider of the social network to eliminate criminally punishable activity on the platform,

- description of the mechanisms for submitting complaints about unlawful content and the criteria applied in deciding whether to delete or block unlawful content,

- $\quad$ number of incoming complaints about unlawful content in the reporting period, broken down according to whether the complaints were submitted by complaints bodies or by users, and according to the reason for the complaint,

- $\quad$ organization, personnel resources, specialist and linguistic expertise in the units responsible for processing complaints, as well as training and support of the persons responsible for processing complaints,

- membership of industry associations with an indication as to whether these industry associations have a complaints service,

- number of complaints for which an external body was consulted in preparation for making the decision,

- number of complaints in the reporting period that resulted in the deletion or blocking of the content at issue,

- $\quad$ time between complaints being received by the social network and the unlawful content being deleted or blocked,

- $\quad$ measures to inform the person who submitted the complaint, and the user for whom the content at issue was saved, about the decision on the complaint.

The best evidence to date about the specific effects of NetzDG comes from the law's transparency requirements. Four major online platforms released their first transparency reports in June 2018:Google (i.e., YouTube), Facebook, Twitter, and Change.org. This provoked another round of debate about the law's impact and efficacy. Perhaps unsurprisingly, opinion remains divided.[6] According to Heldt, after the NetzDG came into force, initial reports reveal the law's weak points, predominantly in reference to their low informative value. When it comes to important takeaways regarding new regulation against hate speech and more channeled content moderation, the reports do not live up to the expectations of German lawmakers.[2]

It is also important to mention that the NetzDG triggered fierce debate and widespread concern about its implications for freedom of expression. The first concern surrounding freedom of expression was that NetzDG would encourage the removal of legal content, also known as "over-removal." Online platforms, it was argued, would not have the expertise or time to assess every complaint in detail. Relatedly, critics objected to NetzDG as an instance of "privatized enforcement" because, rather than courts or other democratically legitimated institutions, platforms assess the legality of content. The NetzDG process does not require a court order prior to content takedowns nor does it provide a clear appeals mechanism for victims to seek independent redress.[7]

\section{France: a European ambition}

France, like Germany, also finds the private regulatory moderation policy of social media inadequate and insufficient. In addition to the aforementioned Loi Avia, the Department for Digitization has put forward a proposal to tackle the problem at EU level. ${ }^{28}$

\footnotetext{
${ }^{28}$ Créer un cadre français de responsabilisation des réseaux sociaux: agir en France avec ambition européenne, Rapport de de la mission 'Régulation des réseaux sociaux - Expérimentation Facebook', Secrétaire d'État chargé du numérique, 2019., https://www.vie-publique.fr/sites/default/files/rapport/pdf/194000427.pdf, (21-01-2020).
} 
the regulation ex ante proposed by the report should respect three conditions: (i) follow a logic of conformity according to which the regulator supervises the correct implementation of preventive or corrective measures, without focusing on the materialization of risks or seeking to regulate the service itself, (ii) focus on systemic actors capable of creating significant damage in our societies without creating a barrier to entry for new European actors, (iii) remain agile in facing future challenges in a particularly scalable digital environment. The legislative system should therefore aim to create an institutional capacity to regulate and not a fixed regulation on current problems. This regulation could be based on the following five pillars:

- $\quad$ First pillar: A public policy of regulation guaranteeing individual freedoms and freedom to undertake platforms.

- $\quad$ Second pillar: Prescriptive and targeted regulation on the empowerment of networks initiatives implemented by an independent administrative authority, based on three obligations incumbent on platforms:

- transparency of the content scheduling function;

- transparency of the CGU implementation and moderation function of content;

$\circ \quad$ a duty of care vis-à-vis its users.

- Third pillar: Informed political dialogue between actors, the government, the legislator, regulator and civil society.

- Fourth pillar: An independent administrative authority partner of the other branches of the state and open to civil society.

- Fifth pillar: A European ambition to strengthen the capacity of member states to act against global platforms, and reduce the political risk linked to implementation in each member state. ${ }^{29}$

\section{Conclusions}

Social media services are difficult to integrate into the existing legal conceptual framework. While, de facto, more and more editorial activities are being performed (directly or through algorithms), social media service remains, de lege, a hosting service under EU law. However, the revision of the AMS Directive has made it possible to extend the scope of media regulation to social media services in respect of elements of the service that meet the Directive's video-sharing platform concept.

Due to the growing impact of social media in our society, the effective removal of infringing content has become a top priority. This issue is also sensitive because action against allegedly infringing content should not lead to a disproportionate interference with freedom of expression. The noticeand-take-down rules of the E-Commerce directive are outdated and will be reviewed this year at EU level. The main question is whether the EU legislature is satisfied with the rules on content moderation being arbitrarily set by the service providers or the it considers that the State should intervene in a more robust manner. German regulations and French proposals point in the latter direction. I do believe that a co-regulation model could be a good compromise where the social media

\footnotetext{
${ }^{29}$ Créer un cadre français de responsabilisation des réseaux sociaux (2019), p. 3.
} 
service providers could keep their limited liability but their internal processes should comply with a clear regulation imposed by the State.

\section{References}

[1] BARTÓKI-GÖNCZY, B., The online intermediaries as the new gatekeepers to the access to information, Pázmány Press, 2018., p. 31.

[2] HELDT, A., Reading between the lines and the numbers: an analysis of the first NetzDG reports, Internet Policy Review, Vol. 8., Issue 2., p. 1.

[3] KOLTAY, A., New Media and Freedom of Expression: Rethinking the Constitutional Foundations of the Public Sphere, HART, 2019, p. 87.

[4] KLEIN, T., Adalékok az online diskurzusok szabályozási kérdéseihez, in: KOLTAY A. - TöRÖK B. (edit.): Sajtószabadság és médiajog a 21. század elején, Wolters Kluwer, 2017, p. 156.

[5] KLEIN, T., Az online diskurzusok egyes szabályozási kérdései, in: Tamás Klein (szerk.): Tanulmányok a technológia- és cyberjog néhány aktuális kérdéseiről, Médiatudományi Intézet, 2019., p. 34.

[6] TWOREK, H., LEERSEN, P., An Analysis of Germany's NetzDG Law, 2019, https://www.ivir.nl/publicaties/download/NetzDG_Tworek_Leerssen_April_2019.pdf, (2401-2020)

[7] TWOREK: An Analysis of Germany's NetzDG Law, Transatlantic Working Group, 2019, https://www.ivir.nl/publicaties/download/NetzDG_Tworek_Leerssen_April_2019.pdf, (2020.04.06.) 